\title{
TEN GELEIDE
}

\section{Tissues voor de rechter}

\author{
Sigrid van Wingerden
}

"If I could fine you for stupid, I would fine you for stupid!" Een dergelijke uitspraak hebben wij de Rijdende Rechter nog nooit horen zeggen, maar zijn Amerikaanse evenknie Judge Judy, die met haar tv-programma meer kijkers trok dan Oprah, staat bekend om haar directheid. Ze spreekt de eisers en gedaagden in haar rechtszaal aan op een manier die ver af staat van hoe wij de communicatie tussen de rechter en de rechtzoekende kennen. ${ }^{2}$ Ziet $u$ het al voor $u$ dat de rechter de gedaagde toebijt: "I eat morons like you for breakfast. You're gonna be crying before this is over!"? ${ }^{3}$ Judge Judy laat zich er graag voorstaan dat ze de mensen die in haar rechtbank verschijnen, aanspreekt op hun eigen verantwoordelijkheid. Zij hoopt ze daarmee lik op stuk te geven, maar ze hoopt er zo ook voor te zorgen dat die mensen - en de negen miljoen mensen voor de buis - zich voortaan verantwoordelijker zullen gedragen. Zij hanteert dus een afschrikkingstactiek.

Hoe anders is het verhaal van de rechter die hetzelfde doel voor ogen staat, maar een heel andere manier heeft om die boodschap te communiceren. Als onderdeel van het 'Consider the Consequences'-programma in de Amerikaanse staat Georgia worden problematische jongeren niet alleen in de gevangenis rondgeleid, zij moeten ook plaatsnemen in een rechtszaal, waar zij toegesproken worden door rechter Velda Colvin. ${ }^{4}$ Colvin toont de jongeren een bodybag terwijl ze uitlegt dat als de jongeren zo doorgaan, ze in de gevangenis eindigen, of in die zak: "And the only way somebody's going to know you're in here is by this tag, that'll have your name on it." Ze vraagt de jongeren vervolgens wat ze willen. Ze wijst de jongeren ook op het geweld in de gevangenis, en dat ze in de gevangenis verkracht zullen worden: "And there's nothing you can do but just lay there, because guess what? Everybody's got to get their turn".

Colvin confronteert de jongeren echter niet alleen met de gevolgen van hun gedrag, ze moedigt ze ook aan om hun levensstijl om te gooien. Zo zegt ze: "You're special and uniquely made. Stop acting like you're trash!" Terwijl de bode tissues uitdeelt aan de huilende jongeren, spreekt Colvin ze bijna aan alsof ze hun moeder is: "Care about your future. Be somebody. Do better than what you've been doing. [...] You are special and you are uniquely made and nobody else can do what you're supposed to do in this world. Nobody else! And if you don't do it, we won't have it." Ten slotte

1 https://en.wikiquote.org/wiki/Judith_Sheindlin.

2 Formeel is er zowel bij Judge Judy als de rijdende rechter geen sprake van rechtspraak, maar van arbitrage.

3 http://www.biography.com/news/judge-judy-quotes.

4 https://www.youtube.com/watch?v=HhvDg9c2Soc. 
wijst ze op het verdriet dat de jongeren hun ouders aandoen: "And when I see you all hurting, it makes me hurt, too. Because I don't even know you all personally, but I love each and everyone one of you [...] and I don't want you to come to my courtroom and I have to sentence you as an adult, at the age of 17. I don't want that. I don't want to experience that myself and I don't want you all to experience that". Dan draait ze zich om en loopt weg. Onderweg naar de deur grijpt zij een tissue mee, omdat ze het zelf ook niet droog houdt.

Rechter Colvin oogst veel lof voor haar optreden: de video van haar toespraak is viral gegaan op internet en in reacties wordt zij geprezen: zo moeten we omgaan met jongeren die we van het criminele pad af willen helpen. En hoewel die reactie bij het publiek begrijpelijk is, is het de vraag of de toespraak de jongeren echt zal aanmoedigen om hun leven te beteren. Uit onderzoek is immers gebleken dat Scared Straight, een enigszins vergelijkbaar programma waarin problematische jongeren geconfronteerd worden met het gevangenisleven met als doel dat ze daar zo van schrikken dat ze hun leven beteren, er ook niet voor zorgt dat jongeren het criminele pad de rug toekeren. Sterker nog, jongeren die zo'n programma hebben gevolgd, plegen juist meer criminaliteit. ${ }^{5}$ Moet rechter Colvin dan maar helemaal stoppen met haar toespraken? Dat moet de toekomst uitwijzen; misschien dat haar aanpak, waarin ze de jongeren niet alleen afschrikt, maar ook moederlijk aanmoedigt wat van hun leven te maken, wel werkt. Het is immers vaak de toon die de muziek maakt.

De communicatie tussen de rechter en de andere mensen in de rechtszaal is niet alleen van belang om ze levenslessen mee te geven, zoals Judge Judy en Judge Colvin dat ieder in geheel eigen toonzetting doen. De communicatie met de rechter is ook van belang voor het gevoel van rechtzoekenden of verdachten dat zij rechtvaardig behandeld zijn. Als mensen zich rechtvaardig behandeld voelen, versterkt dat immers de legitimiteit van de rechtspraak. In Nederland is de rechter die dicht bij de burger staat bij uitstek de kantonrechter. In de eerste bijdrage van dit nummer van PROCES doen Kiki Twisk, Roosmarijn van Es en Rosa Utermark verslag van het onderzoek dat ze verricht hebben onder verdachten van strafkantonzaken in Den Haag. Centraal staat de vraag in hoeverre de verdachten de uitspraak van de kantonrechter als rechtvaardig ervaren en welke kenmerken bepalend zijn voor dit oordeel.

Het PROCESperikel is deze keer geschreven door Cindy Koole en Coosje Peterse naar aanleiding van het tienjarig bestaan van de Vereniging van Nederlandse Jeugdrechtadvocaten (VNJA). De VNJA is opgericht om de rechtspositie en de rechtsingang van minderjarigen te verbeteren. In de afgelopen tien jaar is er veel veranderd op het gebied van het jeugdrecht, maar er zijn nog steeds knelpunten. In deze bijdragen worden enkele van die knelpunten besproken, die nog op het verlanglijstje van de VNJA staan voor het volgende verjaardagsfeest.

In de daarop volgende bijdrage gaat Jeroen Koster in op de uitspraak van de rechtbank in Assen in de zaak van twee moordende broers uit Drenthe. Waarom

5 A. Petrosino, C. Turpin-Petrosino, M.E. Hollis-Peel, J.G. Lavenberg, 'Scared Straight' and other juvenile awareness programs for preventing juvenile delinquency, Cochrane Database of Systematic Reviews 2013, 4. DOI: 10.1002/14651858.CD002796.pub2. 
legt de rechtbank in die zaak geen levenslange gevangenisstraf op? Met het argument dat er in Nederland de facto nauwelijks uitzicht bestaat op vrijlating is Koster het niet eens: volgens hem staan de eisen die uit het EVRM voortvloeien niet in de weg aan het opleggen van een levenslange gevangenisstraf.

Daarna analyseert Janine Janssen hoe de decentralisatie, die waar te nemen is in de veiligheidszorg, zich verhoudt tot de centralisatie, die bij de politie plaatsvindt. Met geweld in afhankelijkheidsrelaties (gia) als voorbeeld laat Janssen zien hoe met beide tegengestelde tendensen soms dezelfde doelen worden nagestreefd.

Dit nummer van PROCES eindigt met de rubriek 'PS van de redacteur', deze keer van de hand van Ad de Beer. 